\title{
PLANT PEST INFORMATION NETWORK (PPIN): AN ACTIVE INFORMATION SYSTEM TO SUPPORT YOUR RESEARCH
}

\author{
K.L. BEAL and A.E. TIER \\ National Plant Pest Reference Laboratory, Ministry of Agriculture and Forestry \\ PO Box 24, Gerald Street, Lincoln 8152, Canterbury, New Zealand \\ Corresponding author: bealk@maf.govt.nz
}

Surveillance information is the cornerstone of New Zealand's agricultural security and market access. Knowledge of our pest and disease status enables the development of quarantine specifications, and supports negotiations with trading partners. The Plant Pest Information Network (PPIN, pronounced 'pippin') is a national database maintained by the National Plant Pest Reference Laboratory (NPPRL), for the collection, collation, management and dissemination of plant pest surveillance information. It holds records of pest/organism occurrence (including fungi, bacteria, viruses, nematodes and insects), their hosts and distribution. The following types of records are reported to the Director Plants Biosecurity and Director Forest Biosecurity of MAF Biosecurity Authority: organisms new to New Zealand, new pest-host associations and new pest distributions. PPIN holds approximately 25,000 records related to significant horticultural/agricultural crops. Other crops, including those of forestry interest, are being included as information is reported or becomes available. Support and input from the scientific community is necessary to build and maintain an accurate, up to date set of surveillance data. New or unpublished records can be forwarded to the PPIN Administrator. In addition, allied organisations (i.e. research institutes, museums and universities) and the public are able to request information from the database.

\section{ODONTRIA SMITHII DEFOLIATES OLIVES IN THE WAIHOPAI VALLEY}

\author{
R.J. TOWNSEND ${ }^{1}$, S. HURNI ${ }^{2}$ and T.A. JACKSON ${ }^{1}$ \\ ${ }^{1}$ AgResearch, PO Box 60, Lincoln, Canterbury \\ ³261 Waihopai Valley Road, Marlborough
}

Adult Odontria smithii were observed defoliating young olive trees (Olea europea) in an organic orchard in the Waihopai valley, Marlborough, in late January 2001. Defoliation continued until mid May with a marked decrease in the numbers of beetles collected from individual trees toward the end of this period. Damage to trees varied greatly with no discernable pattern within the orchard. Soil samples were taken from the orchard and surrounding unimproved grassland and matagouri (Discaria toumatou) scrub in early May but congregations of larvae were not detected. In the laboratory, $O$. smithii adults were found to consume foliage from a range of native trees or shrubs. However, in twoway choice tests, matagouri was the only native foliage that beetles preferred to olive leaves. Commercially available formulations of Pyrethrum and Neem produced a reduction in beetle feeding on olive leaf but caused negligible beetle mortality in laboratory tests. A synthetic pyrethroid treatment (Fastac') reduced feeding to below $1 \%$ of leaf area consumed by untreated beetles and killed $73 \%$ of the exposed beetles over the seven-day trial. Further study into the cause of beetle aggregation and feeding on individual trees may highlight an interception strategy to solve this localised problem. 